\title{
The Copenhagen case-control study of bladder cancer: role of smoking in invasive and non-invasive bladder tumours
}

O MØLLER JENSEN, ${ }^{1} \mathrm{~J}$ WAHRENDORF, ${ }^{2}$ M BLETTNER, ${ }^{2} \mathrm{~J}$ B KNUDSEN, ${ }^{3}$ AND B L SØRENSEN ${ }^{3}$

From the Danish Cancer Registry, ${ }^{\prime}$ Institute of Cancer Epidemiology under the Danish Cancer Society, Landskronagade 66, DK-2100 Copenhagen, Denmark; International Agency for Research on Cancer, ${ }^{2}$ Unit of Biostatistics and Field Studies, Cours Albert Thomas, 69372 Lyon Cedex 08, France; and Finsen Institute, ${ }^{3}$ Department of Surgery, Strandboulevarden 49, DK-2100 Copenhagen, Denmark

SUMMARY A population based study of 388 cases of bladder cancer including papillomas and $787 \frac{\circ}{\widehat{D}}$ controls in Greater Copenhagen confirmed the role of smoking in the aetiology of bladder cancer. ? Significantly increased relative risks were found for persons who had smoked only cigarettes $\triangleq$ $(R R=2 \cdot 9$; both sexes combined) and for mixed smokers including cigarettes $(R R=3 \cdot 6$; both sexes combined). Multiple logistic regression analysis showed significant influences of the amount (pack years) of cigarettes smoked and a reduced risk among persons who had stopped smoking. No significant effects of smoking pipe or cigars/cigarillos were apparent, and the present study does not $\vec{z}$ confirm previous suggestions of associations between the smoking of cigars/cigarillos and bladder cancer in Denmark. Only a slight increase in relative risk with the amount smoked was found. The influence of smoking on bladder cancer risk was similar for tumours in stages $T_{1}$ and $T_{2-4}$ a diagnosis and also for tumours of grades 1-2 and grades 3-4 at diagnosis.

Clemmesen and Nielsen ${ }^{1}$ suggested in the 1950 s that the observed increase in the incidence of bladder cancer (including papilloma) in Copenhagen was due to tobacco smoking. Case-control studies in the second half of the 1950 s confirmed the role of smoking. In Copenhagen, Lockwood ${ }^{2}$ found a clear association between bladder cancer and smoking in particular cigarettes. These early observations supported the finding of bladder tumours in mice after exposure to tobacco tar, ${ }^{3}$ and numerous studies have reported an increased risk of bladder cancer in humans in relation to smoking, as reviewed by Matanoski. ${ }^{4}$

While the association with cigarette smoking seems clear, the role of other types of tobacco, for example cigars and pipes, has not yet been clarified, though it has recently been suggested that cigar smoking is associated with a 3 to 4-fold risk of bladder cancer in Danish women. ${ }^{5}$ The diversity of smoking in Denmark makes it possible to investigate the role of various smoking habits in bladder carcinogenesis.

The aetiology of invasive and non-invasive tumours of the lower urinary tract is in general regarded as identical, and papilloma and frankly invasive tumours of the bladder are often considered together since the distinction between them is difficult and papillomas are assumed invariably to show invasive growth if left untreated. Aetiological research distinguishing between invasive and non-invasive tumours has rarely been carried out, but it was suggested recently that the aetiological role of cigarette smoking is largely confined to non-invasive bladder tumours. ${ }^{6}$

Here we report on the association between various types of tobacco smoking and bladder cancer in Copenhagen and include an examination of the relation to tumours of various grades ${ }^{7}$ and T-stages. ${ }^{8}$

\section{Material and methods}

CASES

The investigation includes tumours located in the $>$ urinary bladder only. As the clinical distinction between non-invasive (papilloma) and invasive $N$ tumours of the urinary bladder is difficult, ${ }^{9}$ they are grouped together as "bladder cancer".

Ascertainment of cases and controls for the study $\mathcal{W}_{\mathrm{C}}$ and the interviewing techniques have been described in $\sigma$ detail elsewhere. ${ }^{10}$ From May 1979 to April 1981, a total of 412 patients living in the municipalities of $\frac{C}{\mathbb{D}}$ 
Table 1 Percentage distribution of cases of bladder cancer in Copenhagen case-control study 1979-81 by histological type and T stage

\begin{tabular}{|c|c|c|c|c|c|c|}
\hline \multirow{2}{*}{$\begin{array}{l}\text { Bladder cancer } \\
\text { characteristic }\end{array}$} & \multicolumn{3}{|c|}{ Men (age, years) } & \multicolumn{3}{|c|}{ Women (age, years) } \\
\hline & -54 & $55-64$ & $65+$ & -54 & $55-64$ & $65+$ \\
\hline Number of cases & $\begin{array}{c}46 \\
(100 \cdot 0 \%)\end{array}$ & $\begin{array}{l}107 \\
(100 \cdot 0 \%)\end{array}$ & $\begin{array}{l}137 \\
(100 \cdot 0 \%)\end{array}$ & $\begin{array}{c}16 \\
(100-0 \%)\end{array}$ & $\begin{array}{c}33 \\
(100-0 \%)\end{array}$ & $\begin{array}{l}49 \\
(100 \cdot 0 \%)\end{array}$ \\
\hline $\begin{array}{l}\text { Transitional cell } \\
\text { tumour, total } \\
\text { Grade 0-2 } \\
\text { Grade } 3-4\end{array}$ & $\begin{array}{l}93 \cdot 4 \\
71 \cdot 7 \\
21 \cdot 7\end{array}$ & $\begin{array}{l}87 \cdot 8 \\
60 \cdot 7 \\
27 \cdot 1\end{array}$ & $\begin{array}{l}86 \cdot 1 \\
54 \cdot 0 \\
32 \cdot 1\end{array}$ & $\begin{array}{l}87 \cdot 5 \\
50 \cdot 0 \\
37 \cdot 5\end{array}$ & $\begin{array}{l}97 \cdot 0 \\
66 \cdot 7 \\
30 \cdot 3\end{array}$ & $\begin{array}{l}83 \cdot 7 \\
59 \cdot 2 \\
24 \cdot 5\end{array}$ \\
\hline $\begin{array}{l}\text { Squamous cell and } \\
\text { solid tumours } \\
\text { Other } \\
\text { Tumour stage, TA } \\
\begin{array}{ll}\text { T0-1 } \\
\text { T2 } \\
\text { T3 } \\
\text { T4 } \\
\text { Unclassified }\end{array}\end{array}$ & $\begin{array}{r}2 \cdot 2 \\
4 \cdot 3 \\
33 \cdot 3 \\
33 \cdot 3 \\
11 \cdot 9 \\
7 \cdot 1 \\
2 \cdot 4 \\
12 \cdot 0\end{array}$ & $\begin{array}{r}3 \cdot 7 \\
8 \cdot 4 \\
34 \cdot 3 \\
31 \cdot 4 \\
7 \cdot 6 \\
11 \cdot 4 \\
4 \cdot 8 \\
10 \cdot 5\end{array}$ & $\begin{array}{r}8 \cdot 0 \\
5 \cdot 8 \\
33 \cdot 8 \\
33.8 \\
9 \cdot 0 \\
14 \cdot 3 \\
1.5 \\
7.6\end{array}$ & $\begin{array}{r}6 \cdot 3 \\
6 \cdot 3 \\
35 \cdot 7 \\
28 \cdot 6 \\
14 \cdot 3 \\
7 \cdot 1 \\
7 \cdot 1 \\
7 \cdot 2\end{array}$ & $\begin{array}{r}0.0 \\
3.0 \\
48.3 \\
31 \cdot 0 \\
3.4 \\
6.9 \\
0.0 \\
10.4\end{array}$ & $\begin{array}{r}10 \cdot 2 \\
6 \cdot 1 \\
29 \cdot 2 \\
27 \cdot 1 \\
6 \cdot 3 \\
18 \cdot 8 \\
8 \cdot 3 \\
10 \cdot 3\end{array}$ \\
\hline
\end{tabular}

Copenhagen and Frederiksberg and the county of Copenhagen were referred to the study, and 389 of these $(94.4 \%)$ were interviewed. A comparison with the records of the Cancer Registry for the population and time period in question shows the case group to be a representative sample of all bladder cancer cases arising in Greater Copenhagen with regard to age, sex, place of residence by area, and occupation.

Some $99 \%$ of the male and all of the female bladder tumours were histologically verified; $89.4 \%$ of all tumours were of the transitional cell type, of which $66.6 \%$ were Bergquist grades 0 to $2 .{ }^{7}$ A total of $61 \cdot 2 \%$ of patients had tumours in stages TA without infiltration or $\mathrm{T} 1$ with infiltration of subepithelial connective tissue only; $3.6 \%$ were $\mathrm{T} 4$ tumours, that is, with fixation. The majority of cases were thus investigated in early stages of the disease. Details of the histological grading and T-staging of the tumours is given in table 1 .

\section{CONTROLS}

Controls were selected at random in April 1979 among the residents of the municipalities where the cases were living. The sample was stratified to group match the cases with regard to sex and five-year age groups. As all controls were drawn at the beginning of the study, some had died or moved out of the area when approached for interview during the following two years. Such controls were replaced by drawing new persons at random from the list of residents in the same age and sex groups. Among 1052 controls approached, the overall participation rate was $75 \cdot 1 \%$, as described previously. ${ }^{10}$

\section{INTER VIEWS}

Interviews were usually conducted in the individuals' homes by trained interviewers, who used a structured questionnaire to obtain information on known or suspected risk factors for bladder cancer. Included were questions on tobacco smoking, drinking of coffee, tea, and other beverages, use of artificial sweeteners, use of drugs, other medical procedures, previous medical conditions, and occupation.

A smoker was defined as a person who had "ever smoked one cigarette, pipe or cigar daily for as long as three months". If a smoker had regularly smoked cigarettes, pipe, cigars, or cigarillos, he/she was asked the age when he/she had started and the age when he/she had stopped smoking a particular type of tobacco.

\section{STATISTICAL ANALYSIS}

The statistical analysis of this unmatched case-control study was done by unconditional maximum likelihood estimation of the parameters of a logistic regression model $^{11}$ using the GLIM package. ${ }^{12}$ The consumption of cigarettes, pipe tobacco, cigars, and cigarillos was calculated as pack-years or pack-year equivalents, ie, $20 \mathrm{~g}$ (1 pack of cigarettes) tobacco smoked per day in one year. One cigar was counted as $\mathbf{5} \mathrm{g}$ tobacco and 1 cigarillo (or cheroot) as $3 \mathrm{~g}$ tobacco, while pipe tobacco was measured directly as quantity consumed per week. The continuous variable for cigarettes was categorised into three different levels to derive category specific relative risk (RR) estimates.

In addition to analysing the data from all cases of bladder cancer, relative risks were also estimated from a logistic regression model in which cases with transitional cell tumours grades 0-2 or 3-4 were compared separately with all controls. Similarly, the relative risks were calculated for development of tumours of stages TA-T1 or tumours of TW-T4 (table 
1). For the logistic regression modelling, the maximum number of individuals with complete information on the variables of interest was used.

\section{Results}

Table 2 shows that approximately $90 \%$ of the adult male and $70 \%$ of the adult female population in

Table 2 Smoking habits in Copenhagen 1979-81, based on information from population controls

\begin{tabular}{lcc}
\hline Characteristic & Men & Women \\
\hline No of controls & 592 & 195 \\
Ever smoked regularly & $88 \cdot 5 \%$ & $66.7 \%$ \\
$\quad$-54 years & $89 \cdot 4 \%$ & $67.9 \%$ \\
$55-64$ years & $89 \cdot 2 \%$ & $74 \cdot 2 \%$ \\
$\quad 65+$ years & $87 \cdot 7 \%$ & $60 \cdot 0 \%$ \\
Ever cigarettes only & $21 \cdot 1 \%$ & $44.6 \%$ \\
Ever pipe only & $3.0 \%$ & $0.0 \%$ \\
Ever cigars or cigarillos only & $4 \cdot 1 \%$ & $9 \cdot 2 \%$ \\
Mixed, with cigarettes ever & $51 \cdot 0 \%$ & $12 \cdot 3 \%$ \\
Mixed, without cigarettes & $9 \cdot 3 \%$ & $0.5 \%$ \\
\hline
\end{tabular}

Table 3 Estimates* of relative risk for bladder cancer for different types of smokers, Copenhagen 1979-81

\begin{tabular}{lrrrl}
\hline Smoking category & Cases & Controls & $R R$ & $95 \% C I$ \\
\hline Non-smoker & 26 & 132 & 1.0 & - \\
Cigarettes only & 115 & 210 & 2.9 & $(1 \cdot 8-4 \cdot 8)$ \\
Pipe only & 6 & 18 & 1.9 & $(0.7-5.4)$ \\
Cigar only & 1 & 2 & 2.5 & $(0.2-28.40)$ \\
Cigarillos & 8 & 39 & 1.0 & $(0.4-2.4)$ \\
Mixed smoker, including cigarettes & 197 & 315 & 3.6 & $(2.2-5 \cdot 8)$ \\
Mixed smoker, excluding cigarettes & 18 & 55 & 1.9 & $(0.9-3.8)$ \\
\hline
\end{tabular}

* Adjusted for age and sex
Copenhagen had been regular smokers at some time before the interview. No major differences are seen between age groups except possibly for a lower proportion of smokers among women aged 65 years or more. Some $60 \%$ of the male population controls have $工$

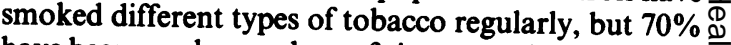

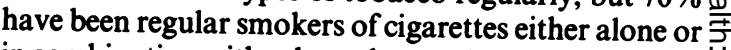
in combination with other tobacco. Almost $60 \%$ of the women have smoked cigarettes regularly.

Smokers of various categories have in general a significantly increased risk of bladder cancer compared with non-smokers. Table 3 shows for the $\frac{\bar{D}}{\vec{D}}$ two sexes combined that significantly increased risks $\stackrel{\mathbb{Q}}{\square}$ are associated with the smoking of cigarettes either $\infty$ alone $(R R=2.9)$ or in combination with other types of tobacco $(R R=3 \cdot 6)$.

The corresponding estimates of relative risk for men and women separately are for smokers of cigarettes alone: men $\mathrm{RR}=4.0(95 \% \mathrm{CI}=1.9-8.6)$ and women $R R=2 \cdot 3(95 \% \quad C I=1 \cdot 2-4 \cdot 3)$. For mixed smokers including cigarettes, men $\mathrm{RR}=4.6(95 \% \mathrm{CI}=2 \cdot 2-9 \cdot 5)$ and women $\mathrm{RR}=3 \cdot 1 \quad(95 \% \mathrm{CI}=1 \cdot 4-7 \cdot 1)$. Nonsignificant increased risks are also noted for pure pipe smokers $(R R=1.9)$ and for mixed smokers who had never smoked cigarettes $(R R=1.9)$. The relative risk associated with ever smoking cigarettes is 2.5 (95\% $\mathrm{CI}=1 \cdot 8-3 \cdot 5$ ), for ever smoking cigars or cigarillos 1.8 (95\% CI $=0 \cdot 8-1 \cdot 3)$, and for ever smoking pipe tobacco $1.4(95 \% \mathrm{CI}=1 \cdot 0-1 \cdot 8)$. As numbers are smat5. and as the type of tobacco is identical, smoking of cigars and cigarillos has subsequently been considered jointly.

Table 4 shows the estimated regression coefficients of ever smoked $(1=$ yes, $0=$ no), stopped smoking $(1=$ yes, $0=$ no), and the continuous variables of pack Table 4 Parameter estimates in multiple logistic regression analysis of bladder cancer with smoking related variables
Copenhagen $1979-81$

\begin{tabular}{|c|c|c|c|c|c|c|c|}
\hline \multirow[b]{2}{*}{ Model } & \multirow[b]{2}{*}{ Deviance } & \multirow[b]{2}{*}{$D F$} & \multirow[b]{2}{*}{ Ever smoked } & \multirow[b]{2}{*}{ Stopped smoking } & \multicolumn{3}{|c|}{ Log pack-year or equivalents } \\
\hline & & & & & Cigarettes & Pipe & Cigars/cigarillos \\
\hline 1 & 1398 & 1136 & $\begin{array}{r}1 \cdot 218^{c} \\
(+/-0.235)\end{array}$ & $\begin{array}{r}-0.542^{c} \\
(+/-0.153)\end{array}$ & & & \\
\hline 2 & 1385 & 1135 & $\begin{array}{r}0.623^{\mathrm{a}} \\
(+/-0.291)\end{array}$ & $\begin{array}{r}-0.478^{b} \\
(+/-0.155)\end{array}$ & $\begin{array}{r}0.088^{c} \\
(+/-0.025)\end{array}$ & & \\
\hline 3 & 1397 & 1137 & & & $\begin{array}{r}0.120^{c} \\
(+/-0.020)\end{array}$ & & \\
\hline 4 & 1382 & 1133 & $\begin{array}{r}0.490 \\
(+/-0.322)\end{array}$ & $\begin{array}{r}-0.451^{b} \\
(+/-0.156)\end{array}$ & $\begin{array}{r}0.095^{c} \\
(+/-0.027)\end{array}$ & $\begin{array}{r}0.037 \\
(+/-0.021)\end{array}$ & $\begin{array}{r}0.002 \\
(+/-0.027)\end{array}$ \\
\hline 5 & 1391 & 1135 & & & $\begin{array}{r}0.121^{c} \\
(+/-0.020)\end{array}$ & $\begin{array}{r}0.047^{\mathrm{a}} \\
(+/-0.021)\end{array}$ & $\begin{array}{r}0.012 \\
(+/-0.019)\end{array}$ \\
\hline \multirow[t]{2}{*}{6} & 1382 & 1132 & $\begin{array}{c}M \quad 0.996^{a} \\
(+/-0.411)\end{array}$ & $\begin{array}{r}0.529^{b} \\
(+/-0.173)\end{array}$ & $\begin{array}{r}0.082^{b} \\
(+/-0.027)\end{array}$ & & \\
\hline & & & $\begin{array}{cc}F & 0.018 \\
(+/-0.556)\end{array}$ & $\begin{array}{r}-0.214 \\
(+/-0.362)\end{array}$ & $\begin{array}{c}0.127 \\
(+/-0.063)\end{array}$ & & \\
\hline
\end{tabular}


The Copenhagen case-control study of bladder cancer

years or pack year equivalents, with a logarithmic transformation with a value for never smoked defined as $\log 0.01$. For each model the deviance is given with the degrees of freedom, and this allows one to assess whether insertion or deletion of a variable affects the goodness of fit significantly.

Smokers have a significantly increased risk of bladder cancer (model 1) with RR 3.4 (men: $R R=4 \cdot 7$; women: $R R=2.5$ ), while those who have stopped smoking have a significantly reduced risk $(R R=0.6)$ compared with current smokers (men: $R R=0.6$; women: $R R=0.6$ ). The amount of cigarettes smoked (pack-years) has a significant influence on the fit of the model (model 2) as its inclusion leads to a substantial reduction in the effect of ever smoking. Pack-years alone can reduce the deviance by 39 with one degree of freedom, and it is thus a highly significant determinant of bladder cancer risk (model 3). Accounting for the amounts of cigars/cigarillos and pipe tobacco smoked does not improve the fit of the model significantly (model 4), although pipe smoking has a marginally significant effect (model 5). The effect of cigar/ cigarillos smoking is not significant.

Risk of bladder cancer is thus adequately determined by age, sex, ever smoked, stopped

Table 5 Relative risk of bladder cancer in Copenhagen 1979-81 in relation to amount of cigarettes ever smoked

\begin{tabular}{|c|c|c|c|c|}
\hline \multicolumn{2}{|c|}{ Amount of cigarettes smoked } & \multirow[t]{2}{*}{ Cases; controls } & \multirow[t]{2}{*}{$\boldsymbol{R} \boldsymbol{R}^{*}$} & \multirow[t]{2}{*}{$95 \% C I$} \\
\hline Pack-years & 1000 cigs & & & \\
\hline $\begin{array}{r}0 \\
1-19 \\
20-39 \\
40+\end{array}$ & $\begin{array}{r}0 \\
-146 \\
-292 \\
292+\end{array}$ & $\begin{array}{r}61 ; 253 \\
101 ; 188 \\
98 ; 167 \\
111 ; 163\end{array}$ & $\begin{array}{l}1.0 \\
2 \cdot 4 \\
2.6 \\
2.9\end{array}$ & $\begin{array}{l}\overline{(1.6-3.5)} \\
(1.8-3 \cdot 8) \\
(2 \cdot 0-4 \cdot 3)\end{array}$ \\
\hline
\end{tabular}

*Adjusted for age and sex

Table 6 Smoking and relative risk for subgroups of bladder cancer including papilloma in Copenhagen 1978-81, men and women combined

\begin{tabular}{|c|c|c|c|c|c|c|c|}
\hline \multirow{3}{*}{$\begin{array}{l}\text { Bladder cancer } \\
\text { category }\end{array}$} & \multirow{3}{*}{$\begin{array}{l}\text { Number } \\
\text { of casess }\end{array}$} & \multicolumn{6}{|c|}{ Smoking variable } \\
\hline & & \multicolumn{2}{|l|}{ Ever smoked } & \multicolumn{2}{|c|}{ Stopped smoking } & \multicolumn{2}{|c|}{$\begin{array}{l}\text { Amount cigarettes } \\
\text { (log pack years) }\end{array}$} \\
\hline & & Regr coeff & $R R$ & Regr coeff & $R R$ & Regr coeff & $R R$ \\
\hline Total & 371 & $\begin{array}{r}0.62^{\mathrm{a}} \\
(+/-0.29)\end{array}$ & 1.9 & $\begin{array}{r}-0.48^{b} \\
(+/-0.16)\end{array}$ & 0.6 & $\begin{array}{r}0.09^{b} \\
(+/-0.03)\end{array}$ & $1 \cdot 1$ \\
\hline $\begin{array}{l}\text { Transitional cell } \\
\text { carcinoma, grades 0-2 }\end{array}$ & 222 & $\begin{array}{r}0.57 \\
(+/-0.35)\end{array}$ & 1.8 & $\begin{array}{r}-0.49^{b} \\
(+/-0.19)\end{array}$ & 0.6 & $\begin{array}{r}0.08^{b} \\
(+/-0.03)\end{array}$ & $1 \cdot 1$ \\
\hline $\begin{array}{l}\text { Transitional cell } \\
\text { carcinoma, grades 3-4 }\end{array}$ & 104 & $\begin{array}{r}0.64 \\
(+/-0.54)\end{array}$ & 1.9 & $\begin{array}{r}-0.37 \\
(+/-0.25)\end{array}$ & 0.7 & $\begin{array}{r}0.11^{b} \\
(+/-0.04)\end{array}$ & $1 \cdot 1$ \\
\hline Stage TA-T1 & 246 & $\begin{array}{r}0.77^{\mathrm{a}} \\
(+/-0.36)\end{array}$ & $2 \cdot 2$ & $\begin{array}{r}0.61^{b} \\
(+/-0.19)\end{array}$ & 0.5 & $\begin{array}{r}0.09^{b} \\
(+/-0.03)\end{array}$ & $1 \cdot 1$ \\
\hline Stage T2-T4 & 90 & $\begin{array}{c}0.60 \\
(+/-0.49)\end{array}$ & 1.8 & $\begin{array}{r}0.42 \\
(+/-0.27)\end{array}$ & 0.7 & $\begin{array}{r}0.06 \\
(+/-0.04)\end{array}$ & $1 \cdot 1$ \\
\hline
\end{tabular}

${ }^{a} p<0.05 \quad b \quad 0.01 \quad c$ Number of controls $=771$ in all analyses smoking, and amount of cigarettes smoked, which are included in model 2. Model 6 shows that the effects are in the same direction for both sexes but that the effect of ever smoking is particularly strong in men while pack-years of cigarettes is the strongest determinant in women.

The relative risks for categories of pack-years of cigarettes are all statistically significant (table 5). The major part of the increase in the relative risk is determined by the transition from non-smoking to ever smoking cigarettes, with a very slight increase in risk with the amount smoked.

The association between smoking and bladder tumours of different grades according to Bergquist's classification or T-stages at the time of diagnosis is given in table 6 . When a comparison is made with smoking habits in the total group of controls, it is seen that the association with smoking is virtually identical for the various subcategories of bladder tumours. In the models, considering simultaneously the effect on bladder cancer risk of ever smoked, stopped smoking, and $\log$ of pack-years of cigarettes, there is an approximately twofold risk associated with ever smoked, a reduction in risk to about 0.6 by stopped smoking, and a relative risk of 1.1 per pack-year, irrespective of grade or stage of the tumour.

\section{Discussion}

The well established association between smoking and bladder cancer is also present in this population based case-control study in Greater Copenhagen. The increased risk is in particular associated with cigarettes whether smoked as the sole source of tobacco or in combination with other types of tobacco among mixed smokers (table 3). The significantly increased risk is seen in both men and women (table 4). The results are 
in line with recent investigations from Europe, North America, and Japan. ${ }^{1320}$ The relative risk estimate is slightly higher than that emerging from most other studies in the United Kingdom, the United States, and Canada, but of the same order of magnitude as in previous studies in Denmark ${ }^{18}$ and Italy. ${ }^{20}$

Both tables 4 and 5 indicate that there is an increase in risk with increasing amount of cigarettes smoked, although the dose response relation is less strong and consistent than is seen for other smoking related cancer, for example, lung, laryngeal, and oesophageal cancers.

The dose response relation also seems less strong in the present study than in a recently reported study from Italy ${ }^{20}$ but more like the uneven patterns described in the United States ${ }^{13}$ and England. ${ }^{19}$ No exact information has been obtainable from the cigarette manufacturers on the composition of Danish cigarettes, but they consist mainly of flue-cured blond tobacco (Virginia tobacco) with the admixture of air-cured black tobacco for certain brands.

The aetiological role of pipe tobacco or cigars in bladder cancer is not clear. Tables 3 and 4 indicate that pipe smoking increases the risk, although it is of borderline significance (table 4). There was also an indication of an increased risk associated with pipe smoking in the study performed in Copenhagen by Lockwood between 1956 and 1958, and a risk of 1.6 relative to the risk in non-smokers can be calculated from the data reported. ${ }^{2}$ By contrast, a study carried out between 1977 and 1980 showed no association with pipe smoking in Danish rural districts and provincial towns. ${ }^{18} \mathrm{~A}$ case-control study from Canada has also provided suggestive evidence that pipe smoking increases the risk of bladder cancer. ${ }^{15}$

Three case-control studies of bladder cancer in Denmark have examined the association with tobacco (table 7). In the case-control study performed in Copenhagen 20 years before the present study, Lockwood reported an association with heavy cigar or cigarillo smoking. ${ }^{2}$ A relative risk of $1 \cdot 1$ can be $\bigcirc$ calculated from the data published, but there is a statistically significant increased risk $(R R=3 \cdot 2)$ 든 among men smoking $31 \mathrm{~g}$ or more of cigars or cigarillos per day, equivalent to approximately seven or more ${ }_{I}$ cigars per day. No dose-response relation is, however, present. In spite of a substantial number of cigar smoking women for whom an overall RR of 1.6 can be calculated, no dose-response relation is seen for that $\stackrel{\rho}{9}$ sex, nor is there an increased risk associated witho heavy cigar smoking among women. By contrast, Mommsen and Aagaard ${ }^{5}$ recently reported an $\frac{\bar{s}}{\overline{\frac{1}{2}}}$ increased risk of bladder cancer among cigar and $\stackrel{\varnothing}{\complement}$ cigarillo smoking women in a case-control study drawing cases and controls from provincial towns and rural districts in Denmark, but no association was seen. in men. ${ }^{18}$ Neither of these previous findings from $\overrightarrow{\vec{\omega}}$ Denmark was confirmed by the present study, which $\stackrel{\omega}{S}$ showed no association with cigar or cigarillo smoking $\overparen{ه}$ (tables 3 and 4) in either men or women when other ?

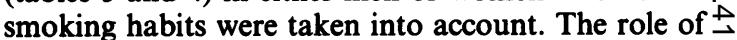
cigar and cigarillo smoking has not been investigated elsewhere in the world.

It has been suggested that cigarette smoking as an 음 aetiological factor is largely confined to non-invasive bladder tumours. ${ }^{6}$ Approximately $90 \%$ of the bladde 3 tumours included in the present study have been $\frac{2}{3}$ classified with regard to clinical T-stage at the time af $\supset$ diagnosis (table 1). For $65-70 \%$ of the cases with $\overrightarrow{0}$ substantial differences between age groups and sexes, there is no clinical sign of invasion at the time of $\square$ diagnosis (TA-T1), while $20-30 \%$ of the cases show invasive growth or spread beyond the bladder wall. There is no indication from the present study that the risks associated with smoking are different for $\frac{}{1}$ tumours that are less (TA-1) or more (T2-4) aggressive.

Some $90 \%$ of the tumours in both sexes and age groups are transitional cell carcinomas, which have been classified according to epithelial differentiation

Table 7 Relative risk of bladder cancer associated with smoking in three Danish case-control studies (smokers v non-smokers)

\begin{tabular}{|c|c|c|c|c|c|c|}
\hline \multirow[b]{2}{*}{$\begin{array}{l}\text { Year } \\
\text { Population covered } \\
\text { Sex } \\
\mathbf{N} \text { of cases; controls }\end{array}$} & \multicolumn{2}{|c|}{ Lockwood, $1961^{2+}$} & \multicolumn{2}{|c|}{ Mommsen, $1985^{518}$} & \multicolumn{2}{|l|}{ Present study } \\
\hline & $\begin{array}{l}\text { 1956-58 } \\
\text { Copenhagen } \\
\text { M } \\
282 ; 282\end{array}$ & $\begin{array}{l}\text { F } \\
87 ; 87\end{array}$ & $\begin{array}{l}1977-80 \\
\text { Rural \& } \\
\text { provincial towns } \\
\text { M } \\
165 ; 165\end{array}$ & $\begin{array}{l}\text { Copenhagen } \\
\text { F } \\
47 ; 94\end{array}$ & $\begin{array}{l}1979-81 \\
M \\
290 ; 592\end{array}$ & $\begin{array}{l}\text { F } \\
98 ; 195\end{array}$ \\
\hline $\begin{array}{l}\text { Cigarettes only } \\
\text { Pipe only } \\
\text { Cigars/cigarillos only } \\
\text { Mixed including cigarettes }\end{array}$ & $\begin{array}{l}2 \cdot 7^{*} \\
1 \cdot 6 \\
1 \cdot 1 \\
3 \cdot 7^{*}\end{array}$ & $\begin{array}{l}3.3 \\
\frac{1}{1.6}\end{array}$ & $\begin{array}{l}3 \cdot 5^{*} \\
6 \cdot 2^{*} \\
2 \cdot 3 \\
7 \cdot 8^{*}\end{array}$ & $\begin{array}{l}3 \cdot 2^{*} \\
\frac{-}{2 \cdot 8}\end{array}$ & $\begin{array}{l}4.0^{*} \\
1.9 \\
1.3 \\
4.6^{*}\end{array}$ & $\begin{array}{l}2 \cdot 3^{*} \\
1 \cdot 3 \\
3 \cdot 1^{*}\end{array}$ \\
\hline $\begin{array}{l}\text { - RR significantly increase } \\
+\quad \text { RR calculated from aut } \\
\text { † Includes prevalent cases }\end{array}$ & & & & & & \\
\hline
\end{tabular}


at the time of diagnosis. If grades 3 and 4 are regarded as more "aggressive" than grades $0-2$, there is no difference in smoking associated relative risk with aggressiveness measured by the degree of differentiation of the tumour (table 6). These results are in line with the results of Lockwood, who found no difference in smoking habits among papilloma patients and patients with invasive bladder tumours. ${ }^{2}$

In conclusion, the present study corroborates the association between smoking and bladder cancer. In both sexes, smoking is the most important determinant of bladder cancer in the present study in which the role of artificial sweeteners, coffee, tea, and beverages, and selected occupations have been reported elsewhere. ${ }^{102122}$ In line with previous investigations, there is a suggestion that pipe smoking increases the risk, while previous reports of bladder cancer in relation to smoking of cigars have not been confirmed. The regression coefficient for the models including pack-years or pack-year equivalents, eg, model 5 , can be used to estimate the relative bladder cancer risk of persons with various smoking histories. Someone who smokes, for example, one pack (20 cigarettes) daily for 40 years has a 2.7 times higher risk of bladder cancer than a non-smoker calculated as $((40 / 0 \cdot 01) 0 \cdot 12=2 \cdot 7)$. The similar relative risk for a pipe smoker who has smoked for 40 years is 1.5 . Table 2 shows that $89 \%$ of all male controls have been regular smokers. Based on this proportion and the weighted relative risks, it can be calculated that the population attributable risk for smoking ${ }^{23}$ is $73 \%$ among men and $48 \%$ among women. This means that some 350 new bladder cancers out of the total number of 420 presently diagnosed in Copenhagen every year ${ }^{24}$ are potentially preventable by cessation of smoking. The present results give a clear indication that cessation of smoking is indeed associated with a decreased risk of bladder cancer development in individuals.

We thank the following hospital departments which reported their patients to the study: Bispebjerg, Department of Surgery D; Hvidovre, Department of Urology; Herlev, Department of Urology; Glostrup, Department of Surgery A; Gentofte, Department of Surgery; Rigshospitalet, Department of Surgery D; Diakonissestiftelsen, Department of Surgery; Skt Lukasstiftelsen, Department of Surgery; Frederiksberg, Department of Surgery K; Sundby, Department of Surgery; Finsen Institute; Sct Elisabeth, Department of Surgery.

Interviews were carried out by Ms H Nøjd and Ms U Larsen. Ms Aa Larsen provided technical assistance with data editing and analysis. Mr G P Sorber assisted with programming, and Ms Aa Falck and Ms M Harnek with preparation of the manuscript. This project was supported by the US National Bladder Cancer Project (Grant No. CA-24119) and by Købmand Peter Bernhard Rasmussen's Foundation.

Address for reprint requests: Dr O Møller Jensen, Danish Cancer Registry, Institute of Cancer Epidemiology under the Danish Cancer Society, Landskronagade 66, DK-2100 Copenhagen, Denmark.

\section{References}

${ }^{1}$ Clemmesen J, Nielsen A. Cancer incidence in Denmark 1943 to 1953 . II. Tumors of urinary system and prostate. Dan Med Bull 1956; 3: 36-43.

2 Lockwood K. On the etiology of bladder tumors in København-Frederiksberg. An inquiry of 369 patients and 369 controls. Acta Pathol Microbiol Scand Suppl 145, 1961.

${ }^{3}$ Holsti LR, Ermala P. Papillary carcinoma of the bladder in mice obtained after peroral administration of tobacco tar. Cancer 1955; 8: 679-82.

4 Matanoski GM, Elliott EA. Bladder cancer epidemiology. Epidemiol Rev 1981; 3: 203-29.

${ }^{5}$ Mommsen S, Aagaard J. A case-control study of female bladder cancer. Eur J Cancer Clin Oncol 1983; 19: 725-9.

${ }^{6}$ Cartwright RA, Glashan RW, Rogers HJ, Ahmad RA, Barham-Hall D, Higgins E. Role of n-acetyltransferase phenotypes in bladder carcinogenesis: A pharmacogenetic epidemiological approach to bladder cancer. Lancet 1982; ii: 842-5.

${ }^{7}$ Bergquist A, Ljungqvist A, Moberger G. Classification of bladder tumours based on the cellular pattern. Acta Chir Scand 1965; 130: 371-8.

8 International Union Against Cancer. TNM classification of malignant tumours. Third edition. Geneva, 1978.

${ }^{9}$ Chisholm GD, Hindmarsh JR, Howatson AG, Webb JN, Bussuttil A, Hargreave TB, Newsam JE. TNM (1978) in bladder cancer. Use and abuse. Br J Urol 1980; 52: 500-5.

10 Jensen OM, Knudsen JB, Sørensen BL, Clemmesen J. Artificial sweeteners and absence of bladder cancer risk in Copenhagen. Int J Cancer 1983; 32: 577-82.

${ }^{11}$ Breslow NE, Day NE. Statistical methods in cancer research. Volume 1 . The analysis of case-control studies. IARC Scientific publications No 32. International Agency for Research on Cancer, Lyon, 1980.

12 Baker RJ, Nelder JA. The Glim System. Release 3. Generalised linear interactive modelling. Oxford: NAG Central Office, 1978.

${ }^{13}$ Cole P, Monson RR, Hanning H, Friedell GH. Smoking and cancer of the lower urinary tract. $N$ Engl J Med 1971; 284: 129-34.

14 Morgan RW, Jain MG. Bladder cancer-smoking, beverages and artificial sweeteners. Can Med Ass J 1974; 111: 1067-70.

${ }^{15}$ Howe GR, Burch JD, Miller AB, Cook GM, Esteve J, Morrison B, Gordon P, et al. Tobacco use, occupation, coffee, various nutrients and bladder cancer. JNCI 1980; 64: 701-13.

${ }^{16}$ Najem GR, Louria DB, Seebode JJ, Thind IS, Prosakowski JM, Ambrose RB, Fernicola AR. Life time occupation, smoking, caffeine, saccharine, hair dyes and bladder carcinogenesis. Int J Cancer 1982; 11: 212-7.

${ }^{17}$ Morrison AS, Verhoek WG, Leck I, Aoki K, Ohno Y, Obata $K$. Artificial sweeteners and bladder cancer in Manchester, UK, and Nagoya, Japan. Br J Cancer 1982; 45: 332-6. 
${ }^{18}$ Mommsen S, Aagaard J, Sell A. An epidemiological case-control study of bladder cancer in males from a predominantly rural district. Eur J Cancer Clin Oncol 1982; 18: 1205-10.

${ }^{19}$ Cartwright RA, Adib R, Appleyard I, Glashan RW, Gray B, Hamilton-Stewart P, Robinson M, et al. Cigarette smoking and bladder cancer an epidemiological inquiry in West Yorkshire. J Epidemiol Community Health 1983 37; 4: 256-63.

20 Vineis P, Frea B, Uberti E, Ghisetti V, Terracini B. Bladder cancer and cigarette smoking in males: case-control study. Tumori 1983; 69: 17-22.
21 Jensen OM, Wahrendorf J, Knudsen JB, Sørensen BL. The Copenhagen case-control study of bladder cancer: II. Effects of coffee and other beverages. Int J Cancer 1986; 37: 651-7.

22 Jensen OM, Wahrendorf J, Knudsen JB, Sørensen BL. The Copenhagen case-control study of bladder cancer study. IV. Occupational factors. Scand J Work Env Health In press.

23 Cole $\mathbf{P}$, MacMahon B. Attributable risk percent in casecontrol studies. Br J Prev Soc Med 1971; 25: 242-4.

24 Danish Cancer Registry. Incidence of cancer in Denmark 1981-82. Copenhagen; Danish Cancer Society, 1985.
Congress of the European Committee for Therapeutic Research in Multiple Sclerosis

3-5 September 1987, Lyon, France.

"Trends in European Multiple Sclerosis Research".

For further information please write to $\mathrm{Dr} C$ Confavreux, Hôpital Neurologique, 59 Boulevard Pinel, 69003, Lyon, France. 